\title{
Microwave and steam blanching as pre-treatments before air drying of Moringa oleifera leaves
}

\author{
Ernest Ekow Abano, ${ }^{1}$ Robert Sarpong Amoah, ${ }^{1}$ Catherine Mbabazi ${ }^{2}$ \\ ${ }^{1}$ Department of Agricultural Engineering, University Cape Coast, Cape Coast, Ghana; ${ }^{2}$ Department of Environment \\ and Livelihood Support Systems, Faculty of Interdisciplinary Studies (FIS), Mbarara University of Science \\ and Technology, Mbarara, Uganda
}

\begin{abstract}
The objective of this work was to identify the optimal drying conditions to produce better quality dried Moringa oleifera leaves with the best drying kinetics using microwave and steam blanching pre-treatments prior to hot air drying. For this purpose, the effect of microwave power, microwave time, steaming time, and air temperature on drying kinetics and quality of Moringa leaves was evaluated using the response surface methodology. In order to achieve a moisture content of $8.0 \% \mathrm{~kg} \mathrm{H}_{2} \mathrm{O} / \mathrm{kg}$ dry matter, the optimal conditions identified were a steaming time of $2.58 \mathrm{~min}(2 \mathrm{~min} 35 \mathrm{sec})$ prior to air drying at $70^{\circ} \mathrm{C}$ and a microwave power of $270 \mathrm{~W}$ for 3 min, followed by air drying at $70^{\circ} \mathrm{C}$. At this optimal condition, a confirmation test for steam-assisted air drying gave a drying time (DT) of $53 \mathrm{~min}$, ascorbic acid (AA) of $2.49 \mathrm{mg} / \mathrm{g}$, and the antioxidant activity (AOA) of $67.244 \%$ inhibition. For microwave-assisted air drying, the confirmation experiment gave a DT of 43 min, AA of $2.699 \mathrm{mg} / \mathrm{g}$, and AOA of $74.46 \%$ inhibition. Both pre-treatments before air drying followed a falling rate drying period at the initial stages and later a constant rate drying period. Our results showed that microwave blanching should be considered as a pre-treatment in industrial production of Moringa leaves to produce better quality dried products in a relatively short time.
\end{abstract}

Correspondence: Ernest Ekow Abano, Department of Agricultural Engineering, University of Cape Coast, Cape Coast, Ghana.

Tel.: +233.542404334 .

E-mail: eabano@ucc.edu.gh ; ekowabano@yahoo.com

Key words: Antioxidant; ascorbic acid; blanching; drying; microwave; Moringa.

Acknowledgements: the authors are grateful for the financial support of the Regional Universities Forum for Capacity Building in Agriculture (RUFORUM) through the METEGA grant toward the study.

Received for publication: 23 December 2019.

Accepted for publication: 3 October 2020.

CC Copyright: the Author(s), 2020

Licensee PAGEPress, Italy

Journal of Agricultural Engineering 2020; LI:1044

doi:10.4081/jae.2020.1044

This article is distributed under the terms of the Creative Commons Attribution Noncommercial License (by-nc 4.0) which permits any noncommercial use, distribution, and reproduction in any medium, provided the original author(s) and source are credited.

\section{Introduction}

Moringa oleifera (Lam) leaves contain high amount of vitamins A, C, calcium, potassium, iron, protein and phytochemicals with powerful anti-cancerogenic and anti-hypertensive activity. These leaves have medicinal properties that can be beneficial against fevers, sore throat, bronchitis, eye and ear infections, scurvy, anaemia, and catarrh. Its antioxidant properties are like those of ascorbic acid, flavonoids, and phenolic acid (Dillard and German, 2000) and make it a valuable alternative food supplement to treat and combat malnutrition, especially among infants and nursing mothers (Iqbal and Bhanger, 2006) in Africa. Fuglie (2001) reported that these leaves can be cooked or used to make soups, sauce and salads. Moringa leaves are fragile and have a high moisture content. After harvest, they are very sensitive to enzymatic activities and microbial damage, also during refrigeration, therefore requiring alternative preservation techniques, such as drying, freezing, or canning, to extend their shelf life.

Drying Moringa leaves is one of the most efficient methods to preserve it. Some studies showed that micronutrients in Moringa are more concentrated in its dried leaves (Fuglie, 2001). Therefore, these leaves are commonly dried and ground into powder and stored at room temperature for months without any appreciable loss of nutritional values. The drying process reduces its moisture content and water activity, thus inhibiting microbial growth and enzymatic activity, and decreasing any degradative reactions. This results in high stability and low transport and storage costs (Alam et al., 2013). Convective hot-air drying is the most common method used to produce dried fruits and vegetables. However, this method is energy intensive due to its long drying times and has some associated degenerative characteristics. As a result, fruits and vegetables to be dehydrated are often submitted to some physical and chemical pre-treatments to reduce the initial moisture content or to modify the vegetable tissue structures so that the air drying process can be faster. These chemical treatments include the use of chemical solutions, such as hyperosmotic substances (Lombard et al., 2008; Deng et al., 2017), alkali, sulphite, acids and gases, such as sulphur dioxide, carbon dioxide and ozone (Deng et al., 2017). The physical treatments include thermal blanching (hot water, steam, superheated steam impingement, ohmic, microwave, infrared, etc.) and non-thermal processes including ultrasound, pulsed electric field, freezing, and high hydrostatic pressure. A comprehensive review of the advantages of physical and chemical pre-treatments employed during drying of fruits and vegetables was published by Deng et al. (2017). Chemical pre-treatments effectively enhance drying kinetics, but they cause leaching of soluble nutrients with associated food safety concerns due to the presence of chemical residues. However, among the emerging pre-treatment technologies for hot air drying, high-humidity hot-air impingement blanching and microwave 
blanching are very promising, because vegetables dried with these methods retain more nutrients compared to those treated with other thermal pre-treatments due to the reduction of leaching losses during blanching (Abano and Amoah, 2015; Deng et al., 2017). The microwave-assisted drying process can be completed in a relatively short time, thus reducing the exposure of food to oxidative reactions and making it possible to remove the moisture content from solids without a liquid phase change. Microwave blanching allows for an efficient heat transfer (Seremet et al., 2016) and requires little or no water, which reduces the amount of nutrient loss in leaching in comparison with boiling water immersion. The objective of microwave-assisted drying is to speed up the drying process, increase the mass transfer, and produce good quality products, while steam blanching prior to drying fruits and vegetables accelerate the drying rate, prevents colour changes, softens the texture, denatures enzymes, and destroys contaminating microorganisms (Ricardo et al., 2018). The increasing demand for plant-based foods in rapid-dehydrated forms has increased the interest in microwave-assisted drying. Consequently, this study was undertaken to investigate the effect of steam and microwave blanching combined with convective hot air drying of Moringa leaves.

\section{Materials and methods}

\section{Sample preparation}

Fresh Moringa leaves for the drying experiments were obtained from Moringa trees at the Technology Village of the University of Cape Coast, Cape Coast, in the Central Region of Ghana. The samples were manually sorted and cleaned to ensure that they were free from insects, branches, dirt and any other foreign matter. The samples were then stored in a refrigerator at $5^{\circ} \mathrm{C}$ in order to minimize the physiological and chemical changes that may occur. The initial moisture content of $3.17 \mathrm{~kg} \mathrm{H} 2 \mathrm{O} / \mathrm{kg}$ d.m. was determined by drying $10 \mathrm{~g}$ of the sample in triplicate at a temperature of $105^{\circ} \mathrm{C}$ for $24 \mathrm{~h}$ in hot-air oven.

\section{Drying experiments}

The Box-Behnken design (BBD) response surface methodology was used to design the drying experiments for microwaveassisted hot air drying. The following three independent variables were used: i) microwave power $\left(\mathrm{X}_{1}\right)$ in watts; ii) microwave pretreatment time $\left(\mathrm{X}_{2}\right)$ in minutes; and iii) air temperature $\left(\mathrm{X}_{3}\right)$ in ${ }^{\circ} \mathrm{C}$ at 3 levels each. Microwave power, duration, and temperature levels were chosen based on preliminary experiments and industrial practices. The range of experimental conditions used for microwave-assisted drying and the results are shown in Table 1. The range of values provided is the same for steam blanching with the exception of power levels. When the drying experiment was completed, the samples were kept in a freezer at $-25^{\circ} \mathrm{C}$ for further analysis.

The effect of the three factors on the three responses (drying time, ascorbic acid, and antioxidant activity) were fitted to a quadratic model. The full model used to describe the dependent variables ( $\mathrm{rr}$ ) involved linear, interaction and curvature effects as shown in Equation (1).

$$
Y_{r}=\beta_{0}+\beta_{1} X_{1}+\beta_{2} X_{2}+\beta_{3} X_{3}+\beta_{4} X_{1} X_{2}+\beta_{5} X_{1} X_{3}+\beta_{6} X_{2} X_{3}+\beta_{7} X_{1}^{2}+\beta_{8} X_{2}^{2}+\beta_{9} X_{3}^{2}
$$

where $b_{0}, b_{1}, b_{2}, b_{3}, b_{4}, b_{5}, b_{6}, b_{7}, b_{8}, b_{9}$, are the regression coefficients; $\mathrm{X}_{1}, \mathrm{X}_{2}, \mathrm{X}_{3}$ are the coded values of the independent variables (microwave power, microwave pre-treatment time and temperature, respectively), while $Y \mathrm{r}$ represents the dependent variables (drying time, ascorbic acid, and antioxidant activity).

The effect of microwave power, microwave pre-treatment time and temperature on ascorbic acid, antioxidants activity, and drying time was analysed. A 2- factor, 3-level factorial design in complete randomization was used to design blanch-assisted air drying. Samples were blanched for 1, 2 and 3 minutes, using steam from boiling water. Subsequently they were exposed to various drying temperatures, i.e. 50,60 and $70^{\circ} \mathrm{C}$. These levels were chosen based on preliminary experiments conducted on Moringa leaves. The distance between the bowl mesh containing the Moringa leaves and

Table 1. Box-Behnken design for three factors and results of microwave drying on drying time, antioxidant activity, ascorbic acid and $D_{\text {eff. }}$

\begin{tabular}{|c|c|c|c|c|c|c|c|}
\hline \multicolumn{3}{|c|}{ Microwave drying conditions } & \multicolumn{3}{|c|}{ Responses } & \multicolumn{2}{|c|}{ Moisture diffusivity } \\
\hline $\begin{array}{l}X_{1} \\
(W)\end{array}$ & $\begin{array}{c}\mathrm{X}_{2} \\
(\mathrm{~min})\end{array}$ & $\begin{array}{c}\mathrm{X}_{3} \\
\left({ }^{\circ} \mathrm{C}\right)\end{array}$ & $\begin{array}{c}\text { DT } \\
(\mathrm{min})\end{array}$ & $\begin{array}{c}\text { AOA } \\
\text { (\% inhibition) }\end{array}$ & $\begin{array}{c}\mathrm{AA} \\
(\mathrm{mg} / \mathrm{g})\end{array}$ & $\begin{array}{c}D_{\text {eff }}\left(\mathrm{m}^{2} / \mathrm{s}\right) \\
\mathrm{E}-9\end{array}$ & $\mathbf{R}^{2}$ \\
\hline 495 & 3 & 70 & 27.5 & 70.697 & 2.758 & 2.05 & 0.9843 \\
\hline 720 & 2 & 70 & 16.5 & 68.889 & 2.934 & 3.13 & 0.9393 \\
\hline 495 & 2 & 60 & 70 & 69.073 & 2.528 & 1.05 & 0.9256 \\
\hline 270 & 2 & 50 & 90 & 60.717 & 3.16 & 0.836 & 0.8914 \\
\hline 270 & 2 & 70 & 60 & 70.253 & 2.735 & 10.09 & 0.9393 \\
\hline 270 & 1 & 60 & 100 & 63.033 & 2.342 & 0.447 & 0.9913 \\
\hline 495 & 2 & 60 & 60 & 66.19 & 2.448 & 9.47 & 0.9647 \\
\hline 270 & 3 & 60 & 65 & 70.416 & 2.371 & 0.947 & 0.9469 \\
\hline 495 & 2 & 60 & 60 & 69.864 & 2.287 & 1.25 & 0.9205 \\
\hline 495 & 1 & 50 & 95 & 63.38 & 3.056 & 0.771 & 0.9255 \\
\hline 720 & 3 & 60 & 50 & 76.672 & 2.231 & 0.869 & 0.7881 \\
\hline 720 & 1 & 60 & 65 & 73.208 & 2.508 & 0.961 & 0.9689 \\
\hline 495 & 3 & 50 & 65 & 66.389 & 3.501 & 1.08 & 0.9632 \\
\hline 720 & 2 & 50 & 55 & 69.117 & 3.135 & 28.28 & 0.9170 \\
\hline 495 & 1 & 70 & 60 & 66.378 & 2.571 & 1.05 & 0.9735 \\
\hline
\end{tabular}

Microwave power $\left(\mathrm{X}_{1}\right)$ in watts, microwave time $\left(\mathrm{X}_{2}\right)$ in min, air temperature $\left(\mathrm{X}_{3}\right)$ in ${ }^{\circ} \mathrm{C}$, drying time (DT) in min, ascorbic acid (AA) in mg/g of DW, and antioxidant activity (AOA) in \% inhibition. 
the boiling water was $10 \mathrm{~cm}$. The pan was tightly covered with a glass lid to prevent the steam from escaping into the atmosphere. After blanching, excess moisture on the surface of the leaves was bloated with absorbent papers. The samples were cooled by natural ventilation and $30 \mathrm{~g}$ each in triplicate were dried in a cabinet oven dryer (GENLAB Oven, Model SDO225, 240AC1PH, $540 \times 920 \times 440 \mathrm{~mm}, 2 \mathrm{~kW})$. The effects of temperature $\left(\mathrm{X}_{1}\right)$ and blanching time $\left(\mathrm{X}_{2}\right)$ on ascorbic acid, antioxidant activity, and drying time was studied. The schematic diagram of the blanching process and the drying equipment used is shown in Figure 1.

During drying, the moisture content dry basis $\left(\mathrm{MC}_{\mathrm{db}}\right)$ and moisture ratio (MR) were calculated using Equations 2 and 3.

$$
\begin{aligned}
& \mathrm{MC}_{\mathrm{db}}=\frac{\mathrm{m}_{\mathrm{t}}-\mathrm{m}_{\mathrm{dm}}}{\mathrm{m}_{\mathrm{dm}}} \\
& \mathrm{MR}=\frac{\mathrm{M}_{\mathrm{t}}-\mathrm{M}_{\mathrm{e}}}{\mathrm{M}_{0}-\mathrm{M}_{\mathrm{e}}}
\end{aligned}
$$

where: $m_{t}$ is the mass of samples at time $t, m_{d m}$ is the mass of dry matter in the sample, $\mathrm{M}_{\mathrm{t}}$ is the dry basis moisture content at time $\mathrm{t}$, $\mathrm{M}_{\mathrm{o}}$ is the initial moisture content, and $\mathrm{M}_{\mathrm{e}}$ is the equilibrium moisture content.

\section{Determination of quality parameters}

We determined the ascorbic acid contents of fresh and dried samples of Moringa leaves spectrophotometrically using a colorimetric analysis method, as previously reported (Abano et al., 2019). The colorimetric analysis of ascorbic acid gives an accurate analysis of the ascorbic acid content since only the dehydro-ascorbic acid reacts quantitatively, unlike the other reducing substances present in the sample extract. The sample weight and reagents were measured using an electronic weighing scale (Sartorius AG Germany, model LE623P) with $\pm 0.0001 \mathrm{~g}$ accuracy. One gram of the sample material was ground mechanically, and $4 \%$ of an oxalic acid solution of the mixture was added, agitated, and filtered. Ten millilitres of the filtered sample was transferred into a $25-\mathrm{mL}$ flask, and bromine water was added until the extract became orange-red. Likewise, ten millilitres of the stock ascorbic acid standard solu- tion was converted into dehydroascorbic acid by bromination. 70.4-563 $\mu \mathrm{g}$ of the standard dehydroascorbic acid solution was pipetted into a series of tubes. Subsequently, different aliquots (0.1-1 mL) of the brominated sample extract were pipetted into test tubes. One millilitre of thiourea was added and then followed by 1 $\mathrm{mL}$ of DNPH (2, 4-dinitrophenylhydrazine) reagent. The blank was prepared in the same way, but distilled water was used instead of the ascorbic acid solution. The contents of the tubes were mixed thoroughly and incubated at $50^{\circ} \mathrm{C}$ in a water bath for $1 \mathrm{~h}$. After the incubation, the resulting orange-red osazone crystals were dissolved by adding $6 \mathrm{~mL}$ of $80 \%$ of sulphuric acid. Absorbance was measured at $540 \mathrm{~nm}$ using a spectrophotometer (Shimadzu, UV mini-1240 UV-VIS Japan). The ascorbic acid concentration was estimated based on the mathematical expression of the calibration curve of ascorbic acid concentration versus absorbance.

The free radical scavenging activity of the extract was measured in terms of radical scavenging ability using the stable free radical DPPH (2, 2-diphenyl-1-picrylhydrazyl) as described by Blois (1958) with modifications. Extraction was performed with $70 \%(\mathrm{v} / \mathrm{v})$ methanol as solvent. The fresh and dried Moringa leaves were ground into a fine powder with a kitchen blender for 2 min, while for fresh Moringa leaves a mortar and pestle were used. One gram of each pounded samples was macerated with $70 \%$ methanol $(1: 20, \mathrm{w} / \mathrm{v})$ for $72 \mathrm{~h}$ at room temperature $\left(28 \pm 2^{\circ} \mathrm{C}\right)$ with occasional shaking. The extract was filtered through a $0.45 \mu \mathrm{m}$ nylon filter membrane, and the marc was re-macerated with the same solvent until the extraction was exhausted. A $0.5 \mathrm{~mL}$ solution of the extract was added to a $0.004 \%$ DPPH solution in methanol. The contents were mixed vigorously and allowed to settle in the dark at ambient temperature for $60 \mathrm{~min}$. A blank solution of methanolic DPPH was also prepared, but with no sample. After a 60 -min incubation period in the dark, the samples and blank absorbance were read at $517 \mathrm{~nm}$ using a spectrophotometer (Kyoto, Japan) Shimadzu UV mini-1240 UV-VIS. Each sample was measured in duplicate. The capability to scavenge the DPPH radical was calculated using Equation 4:

$\mathrm{AOA}=\left(\frac{\mathrm{A}_{0}-\mathrm{A}_{1}}{\mathrm{~A}_{0}}\right) \times 100$

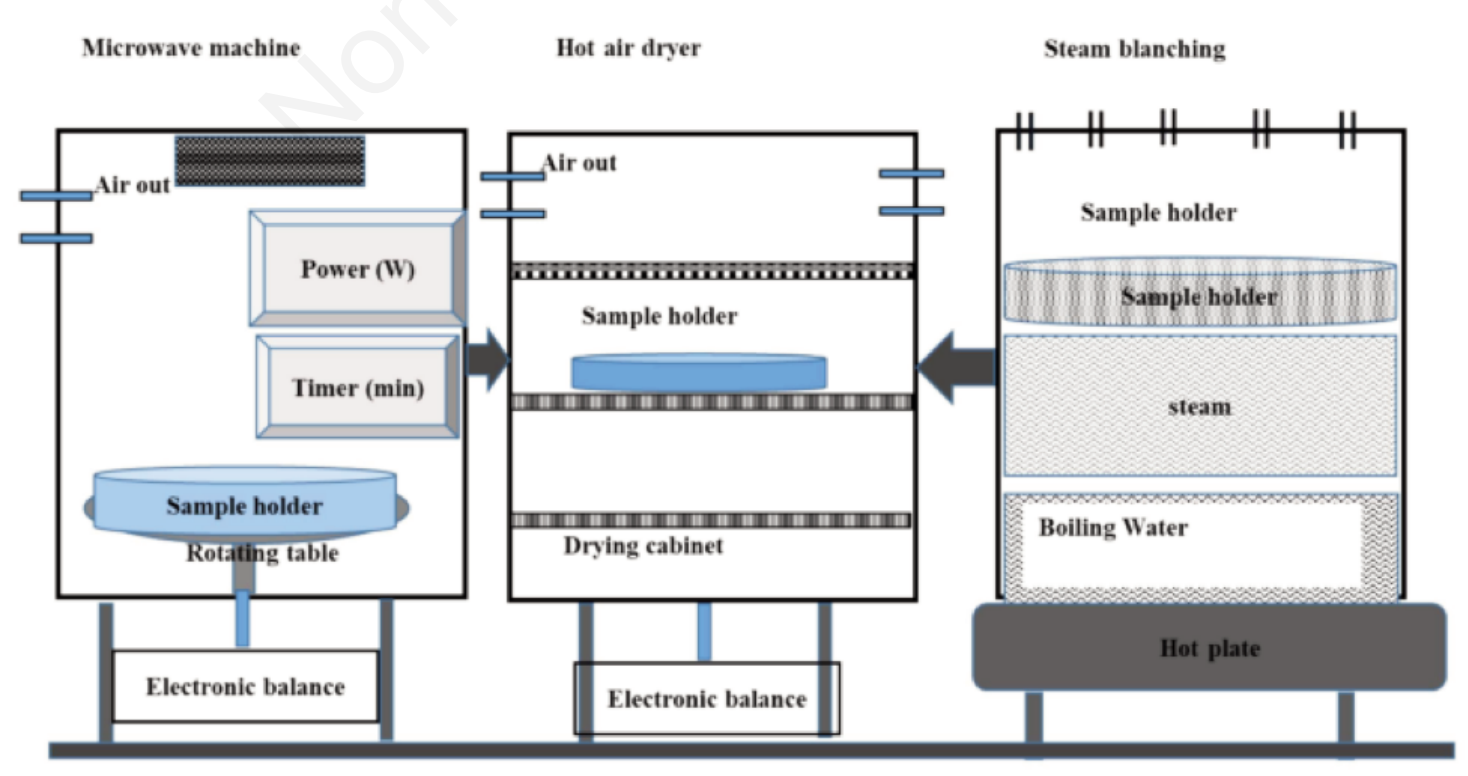

Figure 1. Schematic diagram of microwave, steam blancher and hot air dryer. 
AOA is the antioxidant activity, $A_{0}$ is the absorbance of the blank, $A_{1}$ is the absorbance of the sample.

\section{Energy requirement during drying}

The energy consumption in $\mathrm{kWh}$ of the microwave and the hot air dryer during drying was calculated using Equation 5:

$$
E_{c}=\frac{P t}{1000}
$$

where: $E_{c}$ is the energy consumption in $\mathrm{kWh}, P$ is the power rating of either the microwave equipment or the convective air dryer in $\mathrm{W}$, and $t$ is the drying time in hours.

\section{Optimization studies and statistical analysis}

The drying process's optimization was performed as described in previous studies (Abano and Amoah, 2015) using a multivariate response method called the overall desirability index (DI). Equation (6) was used to determine DI:

$$
D I=\left[\prod_{i=1}^{n} \operatorname{di}\left(Y_{i}\right)\right]^{\frac{1}{n}}
$$

where $n$ represents the number of responses, $d i$ represents the desirability index for each response variable, and $Y_{i}$ is a multivariate optimization approach used to show how desirable the various responses are. This technique has been applied in contemporary optimization models and developed in different fields, including soil temperature, groundwater modelling, and artificial neural network river forecasting (Kazemi et al., 2018). The DI ranges between 0 and 1 with 0 being the least desirable, while 1 is the most desirable. The maximization of the $D I$ value is the aim of optimization studies. The optimization process combines goals and priorities for the factors and responses. In this study, the goal for the factors was at all levels within the range of the design values. However, in the case of responses, the maximum values of ascorbic acid (AA), antioxidant activity (AOA), and minimum values of drying time (DT) were the desired values. A second-order polynomial model was fitted to the mean values of the experimental results to derive the regression equations. Design Expert 9 version: 9.0.6.2 statistical package software was used. The analysis of variance was carried out to find out the statistical significance of the model terms at a probability of 5\%. The accuracy of the model to describe the response variables was measured using the coefficient of determination $\left(\mathrm{R}^{2}\right)$ values. The three-dimensional (3D) surface plots for 2 factors were generated for the various responses.

\section{Results and discussion}

\section{Effects of microwave and steam blanching on drying kinetics}

Figure 2A shows the moisture ratio variation versus the drying time for the various microwave powers of 270,495 , and $720 \mathrm{~W}$
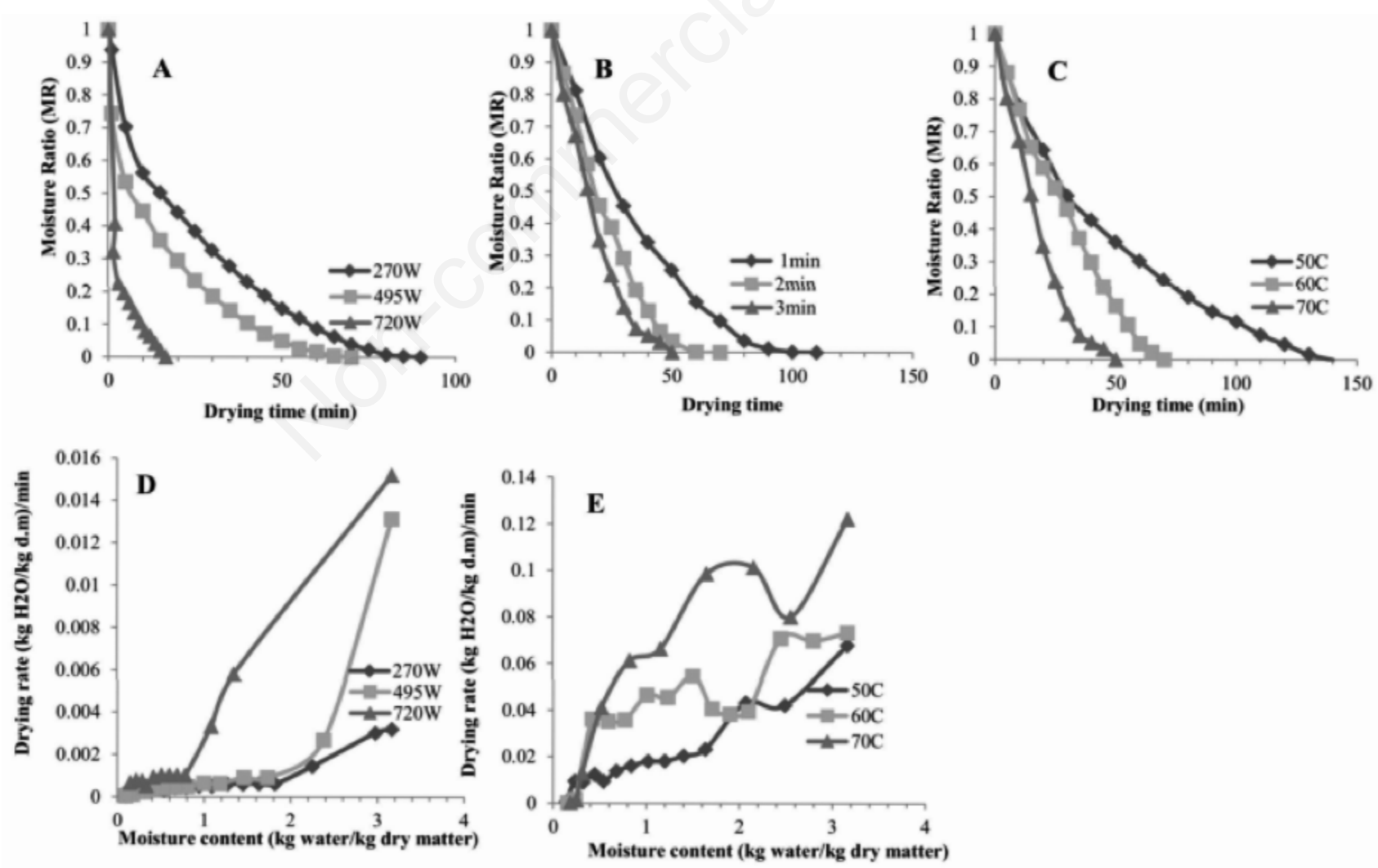

Figure 2. A) Variation of moisture ratio versus drying time for the various microwave powers $(270,495,720 \mathrm{~W})$ and temperatures $(50$, $60,70^{\circ} \mathrm{C}$ ) at MW-pre-treatment time of $2 \mathrm{~min}$. B) Drying time versus moisture ratio for the various microwave powers and temperatures at MW-pre-treatments time of $2 \mathrm{~min}$. C) Drying curves of Moringa leaves dried at $70^{\circ} \mathrm{C}$ for the selected blanching minutes. D) Drying curves of Moringa leaves blanched for $3 \mathrm{~min}$ at the selected hot air temperatures. E) Variation of drying rate against moisture content of Moringa leaves blanched for $3 \mathrm{~min}$ dried at various hot air temperatures. 
and temperatures of 50,60 and $70^{\circ} \mathrm{C}$ at $\mathrm{MW}$ pre-treatment time of $2 \mathrm{~min}$. Microwave power, as well as air temperature, played an important role in affecting the drying time. The increase in microwave power from 270 to $720 \mathrm{~W}$ and air temperature from 50 to $70^{\circ} \mathrm{C}$ increased the mass transfer rate (Figure 2B) of Moringa leaves and eventually reduced the drying time from 90 to $16.5 \mathrm{~min}$. Similarly, the drying rate increased with increased microwave power and hot air temperature (Figure $2 \mathrm{~B}$ ). The drying rate was high at the initial stages of drying and followed a falling rate drying period. The falling rate drying period was steepest for the moisture content between 3.17 and $0.78 \mathrm{~kg} \mathrm{H}_{2} \mathrm{O} / \mathrm{kg} \mathrm{d}$.m. and later slowed for the remaining moisture content (Figure 2A-C).

The results of the fifteen experiments performed according to BBD are shown in Table 1. The main interaction and the curvature effects of the factors on the six responses investigated are presented in Table 2. The main effect of microwave power, pre-treatment time, and air temperature were significant model parameters. However, their interaction and curvature effects gave insignificant model parameters on the drying time of Moringa leaves.

The surface plot from Figure 3 shows that an increase in microwave power, microwave pre-treatment time, and air temperature led to a decrease in Moringa leaves' drying time. These drying parameters had a very high significant effect $(0.01<\mathrm{P}<0.05)$ on the drying time (Table 2 ), which subsequently resulted in significant savings in drying time (Figure 2A-C) compared to the conventional hot air drying (data not shown). The drying time for microwave-assisted drying decreased from 100 to $16.5 \mathrm{~min}$ (Table 1). The lowest drying time was achieved when Moringa leaves were pre-treated in the microwave for $2 \mathrm{~min}$ at a $720 \mathrm{~W}$ power and dried further at a temperature of $70^{\circ} \mathrm{C}$. As microwave power and air temperature increased, the heating energy potentials increased accordingly. These factor increment enhanced the leaves' water molecules' activity, leading to a higher moisture diffusivity, higher drying rate, and decreased drying time. Our results are in keeping with microwave-vacuum drying studies on tomato slices dried between microwave powers of 200 and $700 \mathrm{~W}$ and vacuum pressures between 0.04 and $0.06 \mathrm{MPa}$. The drying time of tomato slices dropped from 84 to $14 \mathrm{~min}$ as the microwave power increased from 200 to $700 \mathrm{~W}$. Microwave-assisted hot air drying can reduce remarkably the drying time of biological materials and save a significant amount of time without damaging the quality attributes of the final products. The results obtained in this study are in agreement with the studies conducted by Abano and Amoah (2015) on white yam, Bouraoui et al. (1994) on potato slices and Premi et al. (2010) on Moringa drumsticks.

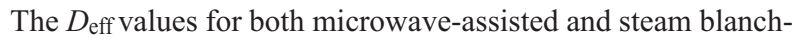
ing drying of Moringa leaves is displayed in Tables 1 and 3,

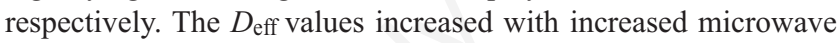
power, microwave pre-treatment time, and air temperature as far as microwave-assisted air drying was concerned. The $D_{\text {eff }}$ for steamblanched leaves increased with blanching time and air temperature.

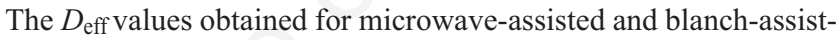
ed drying were within the general range of $10^{-12}-10^{-8} \mathrm{~m}^{2} \mathrm{~s}^{-1}$ for drying of food materials (Doymaz, 2010). The increasing trend of $D_{\text {eff }}$ with temperature supports the hypothesis that the internal mass transfer may influence moisture diffusion through Moringa

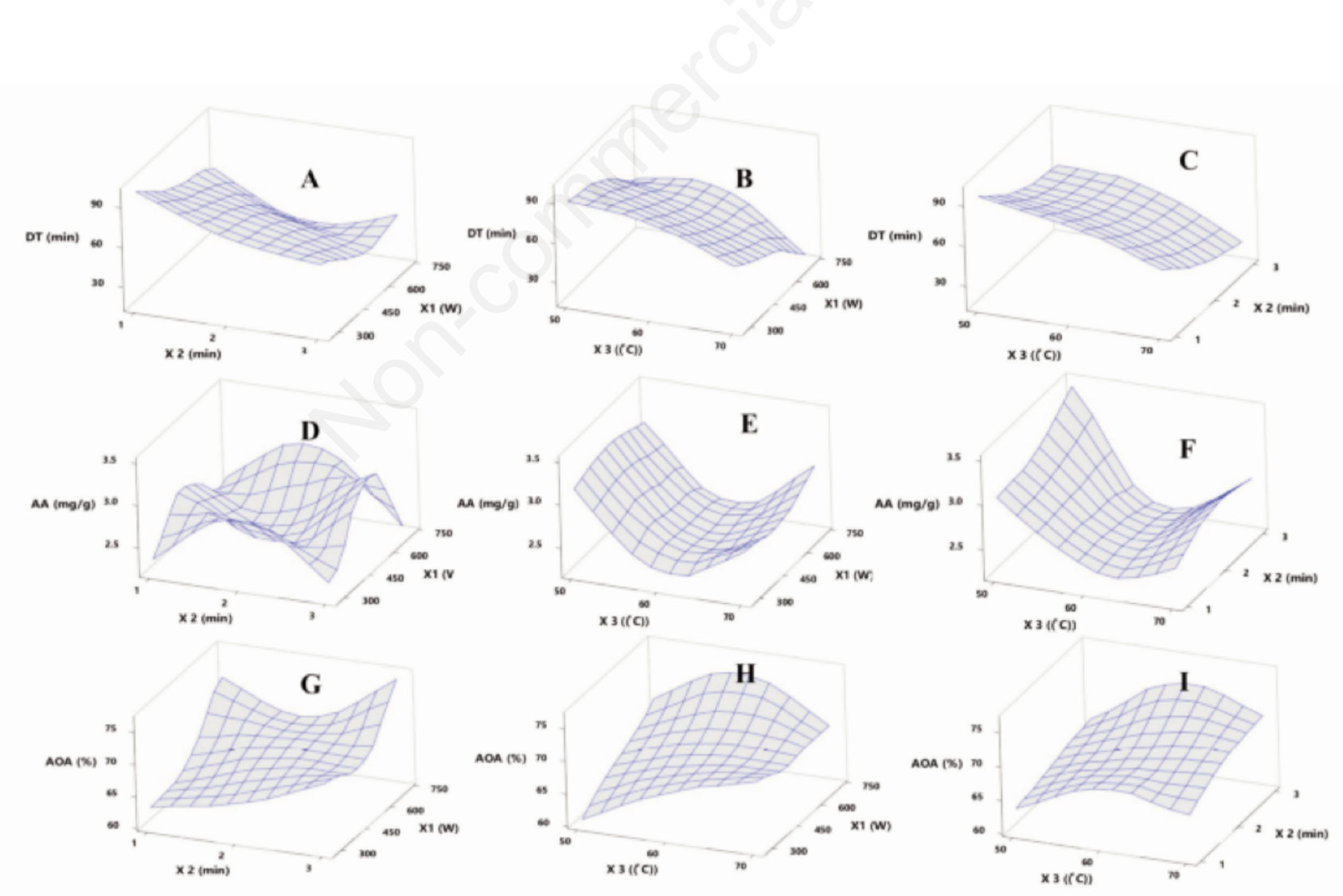

Figure 3. The effect of microwave power $X_{1}$, microwave time, $X_{2}$, and temperature, $X_{3}$, on drying time (DT), ascorbic acid (AA), and antioxidant activity (AOA). 
leaves' tissues. The highest $D_{\text {eff }}$ occurred in Moringa leaves pretreated for $2 \mathrm{~min}$ at a microwave power of $720 \mathrm{~W}$ and dried at $50^{\circ} \mathrm{C}$. The highest effective moisture diffusion for the steam-blanched samples was at a blanching time of $2 \mathrm{~min}$ and subsequent drying at $70^{\circ} \mathrm{C}$. Comparing the highest $D_{\text {eff }}$ in both methods, the effective moisture diffusivity rate in the microwave-assisted drying of Moringa leaves was 30 times higher than in the steam blanched samples. Considering that we dried the microwave and the blanch slices under the same temperature conditions, it means that the microwave pre-treated leaves developed an expanded porous tissue structure with larger pores than the steam pre-treated samples. This higher effective moisture diffusivity in the microwave-assisted dried samples is due to the leaves' volumetric and selective heating by the electromagnetic waves in microwave-assisted drying. Under low pressure, vapour forms quickly inside the product. It generates pressure gradients inside the materials, causing the moisture to flow from the leaves' interior to their surface, increasing the drying rates and moisture diffusivity (Carciofi et al., 2015).

The drying curves of Moringa leaves dried at $70^{\circ} \mathrm{C}$ for the various blanching times are shown in Figure 2B. Table 3 shows the results of the two-factor, 3-level factorial experiment with blanchassisted air drying. It is evident from Table 3 that the drying time decreased from 200 to 50 minutes, as the samples were blanched from 1 to $3 \mathrm{~min}$ and dried at temperatures between 50 and $70^{\circ} \mathrm{C}$. The main effect of the blanching time and the air temperature, as well as the quadratic effect on drying time, was very significant $(\mathrm{P}<0.01)$ (Figure $2 \mathrm{C}$ and Table 4$)$. We observed the lowest drying time at a blanching of $3 \mathrm{~min}$ and an air temperature of $70^{\circ} \mathrm{C}$. The increase in blanching time increased the samples' moisture removal, which ultimately reduced drying time (Figure 2C). In leafy vegetables, blanching is used to inactivate enzymes that catalyse degradation reactions, improve colour retention, and destroy microorganisms during processing. Blanching relaxes leaves' tissue structure, thus causing the cells in the leaves to lose their wall integrity. As a result of this, bound water is lost faster during the drying process than when un-blanched. In this study, an increase in blanching time caused an expansion of Moringa leaves' tissue porous structure and a faster moisture loss. This phenomenon was because blanching removes tissue gases inside Moringa leaves and generates pores within the tissues. The control leaves dried at $70^{\circ} \mathrm{C}$ without pre-treatment took about $110 \mathrm{~min}$ to dry to $0.078 \pm 0.01 \mathrm{~kg}$ water per $\mathrm{kg}$ of dry matter. The effect of blanching time and hot air temperature on Moringa leaves' drying time was in keeping with Doymaz (2012) studies and Premi et al. (2010) on tropical vegetables' persimmon slices Moringa drumstick, respectively. Contrary to our findings, Abano and Amoah (2015) reported an increase in drying time of white yam dried at an air temperature between 70 and $90^{\circ} \mathrm{C}$, as the blanching time increased from 1 to $5 \mathrm{~min}$. In their study, samples blanched for 1 min dried faster than those blanched for $5 \mathrm{~min}$. This contrary behaviour was because when we blanched yam slices for $5 \mathrm{~min}$, the starch might become gelatinized. A higher degree of starch gelatinization shrinks tissue structure and increases the internal resistance to moisture movement (Mate et al., 1998). The blanching time and air temperature model gave an $\mathrm{R}^{2}$ of 0.9673 .

Table 2. Box-Behnken design for three factors and results of coefficient table for model terms and their significance for microwaveassisted drying on drying time, antioxidant activity, ascorbic acid and $\mathrm{R}^{2}$.

\begin{tabular}{|c|c|c|c|c|c|c|c|c|c|c|c|}
\hline Response & $\beta_{0}$ & $X_{1}$ & $\mathrm{X}_{2}$ & $X_{3}$ & $\mathrm{X}_{1} \mathrm{X}_{2}$ & $\mathrm{X}_{1} \mathrm{X}_{3}$ & $\mathrm{X}_{2} \mathrm{X}_{3}$ & $X_{1}{ }^{2}$ & $X_{2}{ }^{2}$ & $\mathrm{X}_{3}{ }^{2}$ & $\mathbf{R}^{2}$ \\
\hline DT & 63.33 & $-13.56^{* *}$ & $-11.56^{* *}$ & $-17.625^{*}$ & 5 & -2.125 & -0.625 & 0.0833 & 6.583 & -8.04 & 0.918 \\
\hline P-value & & $0.0119^{* *}$ & $0.0218^{* *}$ & $0.0041^{*}$ & 0.3609 & 0.6870 & 0.9049 & 0.9878 & 0.2594 & 0.1810 & \\
\hline $\mathrm{AOA}$ & 66.19 & $2.933^{* * *}$ & 2.271 & 2.07675 & -0.98 & -2.441 & 0.3275 & 2.58562 & 2.05262 & -1.535 & 0.742 \\
\hline P-value & & $0.0893^{* * *}$ & 0.1641 & 0.1965 & 0.6403 & 0.2706 & 0.8746 & 0.2632 & 0.3631 & 0.4879 & \\
\hline $\mathrm{AA}$ & 2.421 & 0.025 & 0.048 & $-0.23175^{* *}$ & -0.0765 & 0.056 & -0.0645 & -0.01925 & -0.03875 & $0.589 *$ & 0.913 \\
\hline P-value & & 0.7210 & 0.5005 & $0.0172^{* *}$ & 0.4506 & 0.5755 & 0.5211 & 0.8510 & 0.7070 & $0.0018 *$ & \\
\hline
\end{tabular}

Microwave power $\left(\mathrm{X}_{1}\right)$ in watts, microwave time $\left(\mathrm{X}_{2}\right)$ in min, oven temperature $\left(\mathrm{X}_{3}\right)$ in ${ }^{\circ} \mathrm{C}$; DT, drying time; $\mathrm{AOA}$, antioxidant activity; AA, ascorbic acid. *Significant at $\mathrm{P}<0.01$, ${ }^{* *}$ significant at $\mathrm{P}<0.05$, ${ }^{* * *}$ significant at $\mathrm{P}<0.10$.

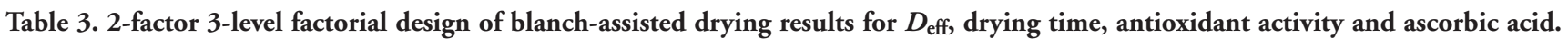

\begin{tabular}{|c|c|c|c|c|c|c|}
\hline \multicolumn{2}{|c|}{ Drying condition } & \multicolumn{3}{|c|}{ Responses } & \multicolumn{2}{|c|}{ Moisture diffusivity and $\mathrm{R}^{2}$} \\
\hline $\mathrm{T}\left({ }^{\circ} \mathrm{C}\right)$ & Bt (min) & DT (min) & $\mathrm{AA}(\mathrm{mg} / \mathrm{g})$ & AOA (\% inhibition) & $D_{\text {eff }}\left(\mathrm{m}^{2} / \mathrm{s}\right) \times 10^{-9}$ & $\mathrm{R}^{2}$ \\
\hline 70 & 1 & 110 & 2.025 & 70.437 & 0.833 & 0.9114 \\
\hline 60 & 3 & 70 & 2.384 & 64.971 & 0.663 & 0.9090 \\
\hline 60 & 2 & 80 & 2.816 & 54.016 & 0.672 & 0.9720 \\
\hline 70 & 3 & 50 & 2.384 & 70.383 & 1.16 & 0.9702 \\
\hline 60 & 1 & 150 & 2.508 & 55.997 & 0.407 & 0.9285 \\
\hline 60 & 2 & 85 & 2.547 & 50.812 & 0.819 & 0.9406 \\
\hline 60 & 2 & 90 & 2.908 & 56.766 & 0.606 & 0.9270 \\
\hline 50 & 1 & 200 & 3.491 & 71.509 & 0.287 & 0.9572 \\
\hline 50 & 2 & 180 & 3.220 & 63.174 & 0.278 & 0.8858 \\
\hline 50 & 3 & 140 & 3.000 & 66.475 & 0.040 & 0.9312 \\
\hline 70 & 2 & 70 & 2.538 & 64.938 & 1.240 & 0.9100 \\
\hline
\end{tabular}

Blanching time (Bt) $(\mathrm{Xl})$ in minutes, temperature $\left(\mathrm{X}_{2}\right)$ in ${ }^{\circ} \mathrm{C}$, drying time (DT) in min, ascorbic acid (AA) in $\mathrm{mg} / \mathrm{g}$ of DW, and antioxidant activity (AOA) in \% inhibition. 


\section{Effect of microwave and steam blanching on quality parameters}

\section{Ascorbic acid}

The effect of microwave power and microwave pre-treatment time for the various air temperatures on the ascorbic acid (AA) content of Moringa leaves is shown in Figure 3. Microwave power and time had a positive effect on the AA content, although it was not significant. This trend supports the observation that microwave blanching prevents leaching losses occurring during conventional steam or water blanching. The primary and quadratic effect of temperature was substantial on the AA content of the leaves. High temperatures and high microwave powers caused a much more significant reduction of the AA content, which was in the range of 2.231$3.501 \mathrm{mg} / \mathrm{g}$ after the drying process, as reported in Table 3 . Compared to the fresh samples, which recorded an AA content of $5.815 \mathrm{mg} / \mathrm{g}$, there was an AA reduction between 40 to $60 \%$ after the microwave-assisted drying of Moringa leaves. An AA reduction between $43 \%$ and $64 \%$ were reported by Tagawaa (2012) for microwave drying of okra fruits. Mrad et al. (2012) observed a $70 \%$ reduction of AA in pears dried at $70^{\circ} \mathrm{C}$. The reduction of AA matches the results obtained by Zheng and $\mathrm{Lu}$ (2011) at the microwave pre-treatment time for different parts of green asparagus. The decline in AA during microwave-assisted drying might be due to the hot air-drying temperatures and the exposure of samples to the hot air, causing both thermal and oxidative degradations.

The effect of blanching time on AA content is shown in Figure 4. The ascorbic acid content ranged from 2.025 to $3.491 \mathrm{mg} / \mathrm{g}$ during blanch-assisted hot-air drying (Table 3). The increase in blanching time and air temperature induced a loss of AA content in Moringa leaves. Air temperature and the combined effect of air temperature and blanching time significantly affected the AA con- tent of Moringa leaves. However, the impact of air temperature was negative on the AA content. The highest retention of ascorbic acid was recorded in leaves blanched for $1 \mathrm{~min}$ and dried at $50^{\circ} \mathrm{C}$ (Table 3). Reduction in AA may be due to its solubility in water during drying and its high vulnerability to heat and oxidative reactions (Abbas et al., 2012). These results agree with reports by Oboh (2005), where blanching caused a significant decrease $(\mathrm{P}<0.05)$ in the vitamin $\mathrm{C}$ content of the vegetables. A significant decrease occurred in Telfairia occidentalis, where blanching caused an $82.4 \%$ loss in the vitamin C content, while in Ocimum gratissimum the loss in vitamin $\mathrm{C}$ content was $47.5 \%$. In this present study, the percentage decrease in ascorbic acid content ranged from 40 to $65.2 \%$ after drying. The percentage range difference might be due to the different durations and thermal treatment approaches used in this study (steam blanching for 1 to $3 \mathrm{~min}$ ). In his research, Oboh used hot water blanching for a slightly longer duration (i.e. $5 \mathrm{~min}$ ). The fitting of the ascorbic acid content gave an $\mathrm{R}^{2}$ of 0.9271 , which is relatively high. Losses of ascorbic acid during blanching prior to drying were also reported in some tropical vegetables. Leaching ascorbic acid through water vapour during blanching may degrade some of the vegetables' ascorbic acid.

\section{Antioxidant activity}

The initial AOA of fresh Moringa leaves was $79.909 \%$ of inhibition. The free radical scavenging ability of Moringa leaves dried by blanching combined with hot air was reduced after drying and ranged from 50.812 to $71.509 \%$ of inhibition (Table 3 ). The results indicated that Moringa leaves' free radical scavenging ability was significantly affected quadratically by both the blanching time and the drying air temperature. The increase in blanching time from 1 to 2 min decreased the AOA of Moringa leaves and afterward increased (Figure 4C). Similarly, the AOA plateaued with air tem-

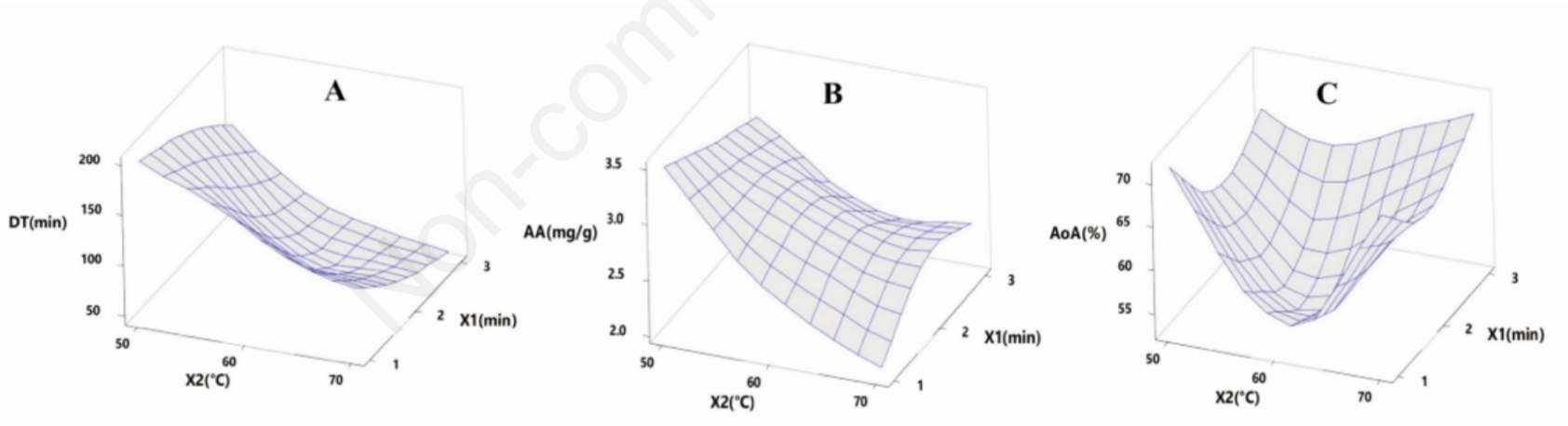

Figure 4. Effect of blanching time $\left(\mathrm{X}_{1}\right)$ and temperature $\left(\mathrm{X}_{2}\right)$ on drying time (DT), ascorbic acid (AA) and antioxidant activity (AOA).

Table 4. Coefficient of the model terms and their significance for steam blanching for drying time, antioxidant activity, ascorbic acid and their $\mathbf{R}^{2}$.

\begin{tabular}{lccccccc} 
Response & $\boldsymbol{\beta}_{0}$ & $\mathbf{X}_{1}$ & $\mathbf{X}_{2}$ & $\mathbf{X}_{1} \mathbf{X}_{2}$ & $\mathbf{X}_{1}{ }^{2}$ & $\mathbf{X}_{2}{ }^{2}$ & $\mathbb{R}^{2}$ \\
DT & 88.16 & $-36.67^{*}$ & $-48.33^{*}$ & $-7.182 \mathrm{E}-15$ & 7.105 & $32.105^{* *}$ & 0.9673 \\
P-value & & $0.001^{*}$ & $0.0003^{*}$ & 1.0000 & 0.4276 & $0.0114^{* *}$ \\
\hline AA & 2.72 & -0.04267 & $-0.4607^{*}$ & $0.2125^{* *}$ & $-0.228^{* * *}$ & $0.205^{* * *}$ & 0.9271 \\
P-value & & 0.5455 & $0.0009^{*}$ & $0.0462^{* *}$ & $0.0739^{* * *}$ & $0.0994^{* * *}$ \\
\hline AOA & 54.07 & 0.647 & 0.7667 & 1.245 & $6.1065^{* *}$ & $9.68^{*}$ & 0.8791 \\
P-value & & 0.672 & 0.6184 & 0.5131 & $0.0405^{* *}$ & $0.007^{*}$ & \\
\hline
\end{tabular}

Microwave power $\left(\mathrm{X}_{1}\right)$ in watts, microwave time $\left(\mathrm{X}_{2}\right)$ in minutes, oven temperature $\left(\mathrm{X}_{3}\right)$ in ${ }^{\circ} \mathrm{C}$, drying time (DT) in minutes, ascorbic acid (AA) in $\mathrm{mg} / \mathrm{g}$ of $\mathrm{DW}$, and antioxidant activity (AOA) in \% inhibition.

*Significant at $\mathrm{P}<0.01,{ }^{* *}$ significant at $\mathrm{P}<0.05,{ }^{* * *}$ significant at $\mathrm{P}<0.10$. 
perature from 50 to $60^{\circ} \mathrm{C}$ and increased after that. However, the main effect of temperature and blanching time was insignificant on the free radical scavenging ability. The results obtained in this study do not match the results reported by Oboh (2005), who stated that there were no changes in the scavenging ability between the blanched and unblanched samples.

The loss in free radical scavenging ability ranged from $5.8 \%$ in Telfairia occidentalis to $51.5 \%$ in Ocimum gratissimum and indicated in his study that blanching drastically reduce the free radical scavenging ability of some tropical green leafy vegetables. Dried Moringa leaves are rich in antioxidant compounds such as ascorbic acid, phenolic acid, and flavonoids (Iqbal and Bhanger, 2006). The AOA inhibition by microwave-assisted hot air drying ranged from 59.645 to $76.672 \%$ (Table 1). Microwave power, microwave pretreatment time, and air temperature increased; also, the inhibition capacity increased (Figure 3G-I) in microwave-assisted dried leaves. However, these increases in the antioxidant inhibition ability were not significant with $\mathrm{P}<0.05$, as reported in Table 4 . In addition, the microwave power and its interaction between pretreatment time and air temperature decreased the AOA of Moringa leaves, but not to a significant extent $(\mathrm{P}<0.05)$. Siddhuraju and Becker (2003) observed a similar result and reported that microwave dried Moringa leaves in the power range of 150 to 900 $\mathrm{W}$ showed a significant increase in AOA.

\section{Energy requirements}

The energy consumption was determined for the control, microwave-assisted, and steam blanch-assisted dried Moringa leaves. The energy consumption obtained for blanch-assisted and microwave-assisted air drying was $1.77 \mathrm{kWh}$ and $0.19 \mathrm{kWh}$, respectively. Steam-assisted hot air drying had the highest energy consumption than the microwave-assisted samples, resulting in about $90 \%$ energy savings. The pieces without pre-treatment required $5.41 \mathrm{kWh}$ of energy to dry. Therefore, using steam blanching before drying led to an energy saving of $67 \%$, whereas microwave blanching led to an energy saving of $96 \%$ compared to hot air alone.

Longer drying time due to lower moisture diffusivity and lower drying rate for steam-blanch-assisted drying increased energy consumption. The higher energy efficiency of microwave due to its volumetric and selective heating compared to steaming could have contributed to this huge saving in terms of energy consumption due to the use of microwave-assisted drying. Similar results were reported by Abano (2016) and Darvishi (2012) for mango and potatoes slices, respectively. Abano found that the energy efficiency percentage of mango was $29.7 \%$. Simultaneously, Darvishi reported that the maximum drying efficiency of potato slices was $62.4 \%$ when microwave-assisted drying was compared to water blanching.

\section{Optimization of the drying parameters}

We created the optimal conditions for drying Moringa leaves with Design Expert 9 version: 9.0.6.2 using the overall desirability index. For blanch-assisted hot air drying, the maximum predicted drying time (DT), ascorbic acid (AA), browning index (BI). and antioxidant activity (AOA) was $53.096 \mathrm{~min}, 2.49 \mathrm{mg} / \mathrm{g}, 2.067 \mathrm{Abs}$ unit and $67.653 \%$ of inhibition. The simulated values were close to their corresponding experimental values of $50 \mathrm{~min} \mathrm{DT,} 3.491 \mathrm{mg} / \mathrm{g}$ AA, $2.516 \mathrm{Abs}$ units BI, and $71.509 \%$ of inhibition. However, in microwave-assisted hot air drying, the maximum predicted DT, $\mathrm{AA}$, and AOA were $42.833 \mathrm{~min}, 2.699 \mathrm{mg} / \mathrm{g}$, and $74.46 \%$ of inhibition, respectively. The simulated values were closer to the corre- sponding experimental values of $16.5 \mathrm{~min}, 3.501 \mathrm{~m} / \mathrm{g}$, and $76.672 \%$ of inhibition, respectively. The overall desirability for blanch-assisted and microwave-assisted hot air drying was 0.62 and 0.58 , respectively. The optimal parameters were a blanching time of $2.58 \mathrm{~min}(2 \mathrm{~min} 35 \mathrm{sec})$, microwave power of $270 \mathrm{~W}$ for 3 $\mathrm{min}$, and an air temperature of $70^{\circ} \mathrm{C}$. At these optimum conditions, a confirmation test for blanch-assisted hot air drying gave a DT of $53 \mathrm{~min}, \mathrm{AA}$ of $2.49 \mathrm{mg} / \mathrm{g}$, the AOA of $67.244 \%$ inhibition. In the microwave-assisted hot air drying case, the confirmation results were as follows: DT was $43 \mathrm{~min}$, AA was $2.699 \mathrm{mg} / \mathrm{g}$, and AOA was $74.46 \%$ of inhibition.

\section{Conclusions}

Microwave power, microwave pre-treatment time, blanching time, and air temperature affected Moringa leaves' drying. The microwave application before hot air drying of Moringa leaves resulted in more porous products and enabled faster removal of moisture in a very short time compared to steam-blanch assisted air drying, leading to significant savings in time and energy required for drying. Microwave as a pre-treatment to air drying offers better quality products in ascorbic acid retention, total phenolic compounds, flavonoids, brown pigment formation, and ultimately enhanced antioxidant activity than steam blanching. Therefore, a microwave pre-treatment before hot air drying is a suitable process for industrial production of dried Moringa leaves, offering products with attractive properties in a very short drying time. To produce better quality Moringa leaves, we recommend blanching for $2 \mathrm{~min} 35 \mathrm{sec}$ or microwave at a power of $270 \mathrm{~W}$ for $3 \mathrm{~min}$ and dry at a temperature of $70^{\circ} \mathrm{C}$.

\section{References}

Abano E.E. 2016. Kinetics and quality of microwave-assisted drying of mango (Mangifera indica). Intern. J. Food Sci. 20:16-21.

Abano E.E., Amoah R.S. 2015. Microwave and blanch-assisted drying of white yam (Dioscorea rotundata). Food Sci. Nutr. 3:586-96.

Abano E.E., Amoah R.S., Opoku E.K. 2019. Temperature, microwave power and pomace thickness on the drying kinetics and quality of carrot pomace. J. Agricult. Eng. L:872.

Abbas S., Da Wei C., Hayat K., Xiaoming Z. 2012. Ascorbic acid: microencapsulation techniques and trends - a review. Food Rev. Intern. 28:343-74.

Alam S., Gupta K., Khaira H., Javed M. 2013. Quality of dried carrot pomace powder as affected by pre-treatments and methods of drying. Agricult. Eng. Intern. CIGR J. 15:236-43.

Blois M.S. 1958. Antioxidant determinations by the use of a stable free radical. Sage, New York, NY, USA.

Bouraoui M., Richard P., Durance T. 1994. Microwave and convective drying of potato slices. J. Food Process Eng. 17:353-63.

Carciofi B.A.M., Teleken J.T., Bertelli V.Z., Prat M., Laurindo J.B. 2015. Experimental approach to evaluate the influence of characteristic length on the Dynamics of biphasic flow in vacuum impregnation. Chem. Engine. Sci. 137:875-83.

Darvishi H. 2012. Energy consumption and mathematical modeling of microwave drying of potato slices. Agricult. Eng. Intern. CIGR J. 14:94-102.

Deng L.-Z., Mujumdar A.S., Zhang Q., Yang X.-H., Wang J., Zheng Z.A., Gao Z.J., Xiao H.W. 2017. Chemical and physical 
pre-treatments of fruits and vegetables: effects on drying characteristics-a comprehensive review. Crit. Rev. Food Sci. Nutr. 59:1408-32.

Dillard C.J., German J.B. 2000. Phytochemicals: nutraceuticals and human health. J. Sci. Food Agric. 80:1744-56.

Doymaz I. 2010. Effect of citric acid and blanching pre-treatments on drying and rehydration of Amasya red apples. Food Bioprod. Proc. 88:124-32.

Doymaz I. 2012. Evaluation of some thin-layer drying models of persimmon slices (Diospyros kaki L.). Energy Convers. Manag. 56:199-205.

Fuglie L.J. 2001. Combating malnutrition with Moringa. pp 117136 in: J. L. Fugile (Ed.), The miracle tree: the multiple attributes of Moringa. CTA Publication, Wageningen, the Netherlands.

Iqbal S., Bhanger M.I. 2006. Effect of season and production location on antioxidant activity of Moringa oleifera leaves grown in Pakistan. J. Food Comp. Analys. 19:544-51.

Kazemi S.M.R., Bidgoli B.M., Shamshirband S., Karimi S.M., Ghorbani M.A., Kwok-wing C., Pour R.K. 2018. A novel genetic-based negative correlation learning for estimating soil temperature. Engine. Appl. Comput. Fluid Mechan. 12:506-16.

Lombard G.E., Oliveira J.C., Fito P., Andrés A. 2008. Osmotic dehydration of pineapple as a pre-treatment for further drying. J. Food Eng. 85:277-84.

Mate J.I., Quartaert C., Meerdink G., Van't Riet K. 1998. Effect of blanching on structural quality of dried potato slices. J.
Agricult. Food Chem. 46:676-81.

Mrad N.D., Boudhrioua N., Kechaou N., Courtois F., Bonazzi C. 2012. Influence of air-drying temperature on kinetics, physicochemical properties, total phenolic content and ascorbic acid of pears. Food Bioprod. Proc. 90:433-41.

Oboh G. 2005. Effect of blanching on the antioxidant properties of some tropical green leafy vegetables. LWT- Food Sci. Technol. 38:513-7.

Premi M., Sharma H.K., Sarkar B.C., Singh C. 2010. Kinetics of drumstick leaves (Moringa oleifera) during convective drying. Afr. J. Plant Sci. 4:391-400.

Ricardo L.M., Jade V.L., Giustino T., Bruno A.M., Carciofi J.B.L. 2018. Microwave vacuum drying and multi-flash drying of pumpkin slices. J. Food Eng. 232:1-10.

Seremet L., Botez E., Nistor O.V., Andronoiu D.G., Mocanu G.D. 2016. Effect of different drying methods on moisture ratio and rehydration of pumpkin slices. Food Chem. 195:104-9.

Siddhuraju P., Becker K. 2003. Antioxidant properties of various solvent extracts of total phenolic constituents from three different agroclimatic origins of drumstick tree (Moringa oleifera Lam.) leaves. J. Agricult. Food Chem. 51:2144-55.

Tagawaa A. 2012. Impact of microwave drying on the quality attributes of Okra fruit. J. Food Process Technol. 46:124-31.

Zheng H., Lu H. 2011. Effect of microwave pre-treatment on the kinetics of ascorbic acid degradation and peroxidase inactivation in different parts of green asparagus (Asparagus officinalis L.) during water blanching. Food Chem. 128:1087-93. 